\title{
Polskie sny literackie
}

Iwona Misiak

TEKSTY DRUGIE 2016, NR 5, S. 163-170

DOI: $10.18318 /$ td.2016.5.11

Sennik polski... ${ }^{1}$ Wojciecha Owczarskiego od razu przywodzi na myśl tytuł powieści Tadeusza Konwickiego Sennik wspótczesny (1963) i to odwołanie jest nieprzypadkowe, ponieważ Konwicki pojawia się w książce Owczarskiego w szkicu Apokryfy pamięci Tadeusza Konwickiego. Ale Sennik polski... powtarza tytuł głośnego spektaklu z 1971 roku - Sennik polski w reżyserii Krzysztofa Jasińskiego², a to nawiązanie nie jest świadome. W przedstawieniu Teatru Stu, które było rozliczeniem z narodową historią, zostały przywołane m.in. utwory Słowackiego, Mickiewicza, Wyspiańskiego, Gombrowicza i Konwickiego, którzy są bohaterami książki Owczarskiego. Spektakl Sennik polski nosił podtytuł: Wiwisekcja polskiej duszy, a wspominam

1 W. Owczarski Sennik polski. Literatura, wyobraźnia i pamięć, słowo/ obraz terytoria, Gdańsk 2014.

2 Na początku lat 70. XX wieku w krakowskim Teatrze Stu powstały trzy legendarne przedstawienia, nazwane przez T. Nyczka tryptykiem pokoleniowym, politycznym i narodowym: Spadanie na motywach poematu T. Różewicza (1970), Sennik polski według scenariusza E. Chudzińskiego i K. Miklaszewskiego (1971) oraz Exodus na podstawie poematu L.A. Moczulskiego (1974).
Iwona Misiak - dr, historyczka literatury, współpracuje z Uniwersytetem Kardynała Stefana Wyszyńskiego, redaktorka kwartalnika „Fraza". Zainteresowania badawcze: literatura polska XX i XXI wieku. Wydała Zmysł czytania (2003) i Początek zagadki. Olabiryntowej twórczości Ryszarda Krynickiego (2015). Kontakt: iwona_misiak@op.pl 
o tym, ponieważ gdański historyk literatury i teatrolog analizuje w swojej pracy funkcjonowanie zbiorowej wyobraźni oraz duchowe życie Polaków³.

We wstępie do Sennika polskiego... autor twierdzi, że senna i nocna strona polskiej kultury jest słabo rozpoznana, dlatego postuluje podjęcie pogłębionych badań nad marzeniami sennymi, wyobraźnią i pamięcią w literaturze i polskiej rzeczywistości społecznej. Podkreśla, że dream studies od dawna rozwijają się w Europie Zachodniej i Stanach Zjednoczonych: „Jaka szkoda, że podobnych badań nikt nigdy nie zainicjował w Polsce!"4. Wymienia dotychczasowe i najważniejsze studia oniryczne autorstwa m.in. Jerzego Jarzębskiego, Danuty Danek, Michała Głowińskiego, Jana Błońskiego, Aleksandry Okopień-Sławińskiej, Marii Podrazy-Kwiatkowskiej, Aliny Witkowskiej, Marii Piaseckiej. Wskazuje również na tom Oniryczne tematy i konwencje w literaturze polskiej XX wieku pod redakcją Ilony Glatzel, Jerzego Smulskiego i Anny Sobolewskiej (1999), akcentując, że wyznaczył on zwrot oniryczny w polskim literaturoznawstwie. Narzeka na niewielką liczbę monografii (ale takie monografie powstają, np. książka Marcina Pliszki Wonirycznym teatrze. Sen w poezji polskiego baroku ${ }^{5}$ ).

Po wstępnych nawoływaniach do stworzenia projektu realizowanego przez dużą grupę badaczy: „antropologów, kulturoznawców, psychologów, socjologów, historyków literatury", który miałby zaowocować zbiorem marzeń sennych czy też zapoczątkować opracowywanie dzienników snów „prowadzonych przez różne osoby"7, Owczarski wyznacza sobie odmienne, „nieporównanie skromniejsze"8 zadanie, tzn. analizę snów literackich

3 "O czym śnią Polacy? Czy mają kolorowe sny? Czy i jakie prześladują ich koszmary? To niesłychane, ale - o ile mi wiadomo - nikt dotychczas nie przeprowadził w tym zakresie choćby wstępnych badań. Nikt nie zadał sobie trudu, aby zapytać Polaków o ich marzenia senne [...]. Mimo dobrego samopoczucia kulturoznawców, antropologów, różnego rodzaju specjalistów od polskiej duszy, duchowe życie Polaków pozostaje sferą rozpoznaną bardzo słabo" (W. Owczarski, Sennik polski, s. 5). Autor stwierdza: „Należałoby [...] na serio zainteresować się fenomenem kolektywnej wyobraźni Polaków, a najlepszym źródłem jej poznania wydaje się [...] powszechny rejestr snów", w którym znajdą się skatalogowane sny "Kowalskiej i Nowaka" (tamże).

4 Tamże, s. 8.

5 M. Pliszka W onirycznym teatrze. Sen w poezji polskiego baroku, Wydawnictwo UPH, Siedlce 2015.

6 W. Owczarski Sennik polski.

7 Tamże, s. 9.

8 Tamże, s. 10. 
w twórczości Juliusza Słowackiego, Stanisława Wyspiańskiego, Bolesława Leśmiana, Brunona Schulza, skamandrytów (Iwaszkiewicza, Wierzyńskiego, Tuwima), Krzysztofa Kamila Baczyńskiego, Witolda Gombrowicza, Tadeusza Konwickiego, Tadeusza Kantora, Olgi Tokarczuk. W rozdziale Od dziennika do sennika wymienia innych polskich pisarzy i pisarki, dodatkowo omawiając dzienniki Jana Lechonia i Marii Dąbrowskiej, a także zapiski Mariana Marzyńskiego, prozę Krystyny Sakowicz, utwory Adama Wiedemanna i książki Agnieszki Taborskiej. Domyślam się, że autor w śmiały sposób chciał złączyć wiele tematów z różnych okresów, których wyróżnikiem jest sen literacki. W ostatnim rozdziale Sny w „domach starców” Owczarski ponownie wraca do sygnalizowanych we wstępie snów Polaków. Analizuje to, co śni się starszym kobietom i mężczyznom w domach opieki, zastanawiając się, czy ich sny mogą mieć działanie terapeutyczne (notabene, czy literaturoznawca, przeprowadzając ankiety i wywiady w domu opieki nad starszymi osobami, nie wkracza przypadkiem w obszar kompetencji psychoterapeuty?). Książka Owczarskiego, tak dramatycznie rozdarta na wstępie, pod koniec traci na wyrazistości, lecz jej zasadnicza część jest poświęcona analizom snów literackich, a przyjęta metodologia wyrównuje te rozbieżności.

Zdaniem badacza literackie sny „odzwierciedlają proces kształtowania się tożsamości”. Analiza indywidualnych tożsamości śniących nie staje się jednak punktem wyjścia do skonstruowania tożsamości zbiorowej - „narodowej, historycznej, społecznej, pokoleniowej - to już Czytelnik będzie musiał rozstrzygnąć sam", zaskakująco puentuje Owczarski. Podobnego skoku myślowego dokonuje, omawiając dyskurs tożsamościowy, tzn. stwierdza, że „nie ma potrzeby przypominać jego specyfiki”,,nie ma też sensu rozwodzić się nad - doświadczanym mniej lub bardziej boleśnie - kryzysem podmiotowości"10. Wspomina więc krótko o podstawowych przemyśleniach Charlesa Taylora, ale nie wypowiada się na temat teorii Derridy, lakonicznie przywołuje Deleuze'a i Lacana, częściej dwa terminy Kristevej: wstręt i abiekt. Przypomina za to obszerniej poglądy Freuda, Junga, Bachelarda, dwóm pierwszym poświęcając osobne rozdziały. Natomiast starannie przybliża koncepcje z zakresu dream studies: Calvina Halla, Medarda Bossa, J. Allana Hobsona, Ernesta Hartmanna, Jeanette Marie Mageo i Carol Schreier Rupprecht. W tym interesującym fragmencie książki Owczarski prezentuje m.in. dwie polemiczne tezy Halla i Hartmanna.

Tamże, s. 11.

10 Tamże, s. 13-14. 
Calvin Hall jest przekonany, że istnieje ciągłość między podmiotem śniącym i podmiotem na jawie. Uważa, że niezmienność snów, które badał na przestrzeni lat podczas terapii, potwierdzają jedność i stabilność podmiotu: "«Sny są tożsame z życiem na jawie, świat snów i świat jawy jest jeden i ten sam»"1. Zdaniem Ernesta Hartmanna, twórcy Współczesnej Teorii Śnienia, sny wydają się nam obce, z różnych względów traktujemy je jako nienależące do naszego życia na jawie, ale z drugiej strony sny nie różnią tak bardzo od jawy. Sen jest nietożsamy z myśleniem, lecz związany z percepcją i stanowi jeden z biegunów kontinuum, którego przeciwnym krańcem jest jawa. Z kolei Jeanette Marie Mageo stwierdza, ,że «ja» nie tylko odzwierciedla się, lecz także, w znacznym stopniu, tworzy się w snach"12 - sen wpływa na kształtowanie się tożsamości na jawie.

Sny są traktowane przez współczesnych badaczy jako czynnik konstruowania tożsamości i utrwalania wspomnień albo odwrotnie - celem snów jest pozbywanie się niechcianych lub zbędnych informacji. Według Hartmanna, sny łączą wspomnienia z nowymi doświadczeniami za pomocą emocji, wytwarzając poczucie sensu i tożsamości. Sen ma siłę kreacji, a nie tylko repetycji - jest zakorzeniony w przeszłości śniącego, otwarty na teraźniejszość i działanie wyobraźni. Marzenia senne wzmacniają i bezustannie przeobrażają podmiot śniący. Teoria Hartmanna jest ważnym punktem odniesienia dla Owczarskiego ze względu na twórczy potencjał snu funkcjonującego na styku pamięci i wyobraźni.

Autor Sennika polskiego... zajmuje się problematyką procesu twórczego i psychologii twórczości, podejmuje dyskusję z aktualizowanymi wzorcami mitycznymi i archetypicznymi, analizuje podmiot we śnie i na jawie, a także bada wzajemne relacje snu i pamięci, snu i wyobraźni oraz związki między snem i jego literackimi kontynuacjami. Istotną kwestią jest ustalenie, czy sen literacki powinien być traktowany inaczej niż zwykły sen i odróżniany od niego. Badacz przypomina zdanie Freuda, że każdy sen jest wtórnie opracowanym i zniekształconym opisem marzenia sennego, a także przywołuje pragmatyczne rozwiązanie Calvina Halla, który proponuje postawić znak równości między snem i relacją ze snu w celu swobodnego analizowania opowiadanych/zapisanych snów. Nieistotna staje się różnica między prawdą a zmyśleniem. Sen literacki jest podporządkowany konwencjom i pisarskim strategiom, zaznacza Owczarski, lecz z tych powodów nie należy zamykać go

11 Tamże, s. 16.

12 Tamże, s. 23. 
„W tradycyjnych kategoriach poetyki”, powinien czerpać „inspiracje płynące z innych dziedzin dream studies" ${ }^{\prime 13}$. Podkreśla, że Carol Schreier Rupprecht koncentruje się na interdyscyplinarnym i komparatystycznym podejściu do materii snów, łącząc fenomen snu z jego językowym czy też literackim przekazem., Sen literacki”, podsumowuje Owczarski, ,jest snem i jest literaturą”14. A powodem, dla którego bada sny literackie, jest to, że dostrzega w nich intrygujące „zwierciadło ludzkiej tożsamości”'15. Sen jest swoistym punktem wyjścia do pełnego opisu tożsamości - zarówno dla pisarza, jak i interpretatora.

Owczarski analizuje na przykładzie fragmentów wierszy Mickiewicza (Śniła się zima...), Różewicza (Elegia prowincjonalna) i Miłosza (Obudzony) formowanie się tożsamości podmiotu, który nazywa za Georges'em Pouletem "cogito" danego twórcy. W tych trzech utworach tożsamość „ja” konstytuuje się na granicy snu i jawy. W wierszu Mickiewicza sen trwa po przebudzeniu, podmiot ze snu jest tożsamy z tym na jawie, w onirycznej elegii Różewicza podmiot odcięty od przeszłości i przyszłości, powstaje wciąż na nowo, gotowy do kolejnych przebudzeń i samookreśleń, a w utworze Miłosza pobudka jest mistycznym poczuciem szczęścia, które ujawnia się w perspektywie końca życia, tak samo silnie we śnie i na jawie. Owczarski nazywa te wiersze „epifaniami przebudzenia"16 i wyznaczają one następne punkty, a właściwie zawęźlenia między snem a jawą w twórczości innych poetów i pisarzy przywołanych w Senniku polskim.

Śniący podmiot jest zagrożony dezintegracją (Słowacki), sen niekiedy bywa skutkiem niespójności „ja” (Wyspiański), czasem podmiot całkowicie traci swoją tożsamość i przeistacza się w obce byty oniryczne (Leśmian), sen, świat i podmiot we śnie mogą wydawać się abiektalne (Schulz). Skamandryci raczej cierpieli na bezsenność, a jawa fascynowała ich w większym stopniu niż sny, w których musieli konfrontować się z ciemnymi aspektami życia. Sny w poezji Baczyńskiego zwykle były traumatycznymi koszmarami wojennymi zakorzenionymi w nocnej wyobraźni podmiotu. Gombrowicz wykorzystywał poetykę snu do rozluźniania i kondensowania opisywanych

13

14

Tamże, s. 30.

Tamże, s. 32.

Tamże, s. 33. Lustro tożsamości może czasem przypominać gabinet luster w lunaparku literatury, a jednym z przykładów jest cykl opowiadań Sny o snach A. Tabucchiego, który nie poznawszy snów swoich ulubionych twórców, napisał zastępcze, czyli własne wersje ich marzeń sennych (w: tegoż Sny o snach, Czytelnik, Warszawa 1997, s. 103-166).

6 Tamże, s. 34 . 
zdarzeń, a także do niwelowania różnic między „ja” realnym a „ja” wyobrażonym/wyśnionym - jego bohaterowie śnią świadomie i sterują przebiegiem snów. Owczarski przypomina w tym miejscu o zjawisku śnienia jasnego. Zdaniem Allana Hobsona jest to fenomen z pogranicza czuwania i snu, kiedy podmiot znajduje się w trzecim stanie świadomości. „Okazuje się bowiem, że możliwe są takie wymiary istnienia, które kwestionują rozdział między wnętrzem i zewnętrzem, między «ja» $\mathrm{i}$ «nie-ja». Podmiot snu jasnego nie jest ani podmiotem, ani przedmiotem: nie jest tym, kto śni, ani tym, o kim śni. Jest różnicą - w znaczeniu, jakie temu terminowi nadał Deleuze: «różnicą samą w sobie»"17 - czyli różnicą niepodporządkowaną stabilnej tożsamości ani żadnym binarnym podziałom. Owczarski, powołując się na rozpoznania Michała Pawła Markowskiego, opisuje luźną konstrukcję podmiotu w utworach Gombrowicza, tzn. postępuje według normy wyznaczonej przez autora Operetki: cyklicznego niszczenia i tworzenia formy. Derridiańska widmowość, czyli ambiwalentny stan życia w śmierci i śmierci w życiu wedle formuły Yeatsa ( $\mathrm{z}$ wiersza Bizancjum), stawanie się heterogenicznego podmiotu, rizomatyczny model świata i nomadyczność Deleueze'a, utopia/ heterotopia Foucaulta, międzypokoleniowe dziedziczenie traumy i nieświadomości w ujęciu Abrahama i Török, współczesne teorie traumy, np. Cathy Caruth, nie są przedmiotami uwagi badacza, choć wymienione kategorie przystają do podjętej przez niego analizy snu i sytuacji śnienia. W rozdziale poświęconym twórczości Gombrowicza pojawia się Realne Lacana, lecz sądzę, że ta problematyka wymagałaby rozwinięcia ze względu na to, że pojęcie traumy powraca w książce Owczarskiego, np. w Apokryfach pamięci Tadeusza Konwickiego. Autor Sennika wspótczesnego programowo odcinał się od twórczej, a także traumatycznej siły snów, lecz senne zjawiska permanentnie pojawiały się w jego prozie, uruchamiając pracę pamięci i wpływając na nieciągłość „ja”. Podobne było stanowisko Tadeusza Kantora, który utrzymywał, że wyobraźnia nie rodzi się ze snu, choć w jego teatrze sen był w naturalny sposób spokrewniony ze śmiercią, podmiot rozbity, a tożsamość zwielokrotniona ${ }^{18}$.

17 Tamże, s. 164. M. Głowiński opisuje świadome śnienie, które nazywa epifanią, w opowiadaniu otwierającym tom Carska filiżanka (Wielka Litera, Warszawa 2016).

18 Te wyznaczniki twórczości Kantora zjawiają się w jego albie (nieprzywołanej przez Owczarskiego): „żeby tylko ta / chwila szczególna / nie uleciała, / jest przed świtem/ godzina 4 ta / nad ranem - / ta szczególna / chwila, która / jest wątłym / przedłużeniem snu [...] żeby jakimś / sposobem ten sen / przedłużać - / rozbudowywać - / snu nie można / budować - / jest jak dym [...] - żeby tylko / ta chwila przed świtem / nie uleciała / trzeba się spieszyć - / bo za chwilę 
Z wielu mniej lub bardziej zajmujących wątków w Senniku polskim... Wojciecha Owczarskiego wyróżniam próbę zarysowania historii śniącego podmiotu i zbiorowości oraz tematykę doświadczania wydarzeń historycznych i przeżywania zdarzeń traumatycznych w (jednostkowych i kolektywnych) snach literackich. Jednocześnie sądzę, że te dwa zagadnienia zapowiedziane przez autora mogłyby być materiałem na osobną publikację. Poza tym zastanawiam się, jak odpowiedzieć na dwa ważne pytania nasuwające się po lekturze Sennika polskiego. Pierwsze z nich brzmi: czy sen służy do poznania siebie i czy pomaga stworzyć/odtworzyć własną tożsamość? A drugie: czy podmiot, który śni, staje się bardziej bohaterem historii własnej czy zbiorowej? W przebiegu tych dwu zjawisk często pojawiają się pęknięcia i szczeliny. Trauma jako kryzys egzystencjalny i twórczy pojawia się w snach pisarzy i pisarek przywołanych przez Owczarskiego, podlega symbolizacji i opiera się jej, wywołując koszmary. W snach w sposób niekontrolowany i zagadkowy wracają wydarzenia z przeszłości, uporczywie drążąc świadomość i nieświadomość. Jest to jedna z przyczyn rozdźwięku między rzeczywistością a Niesamowitym Freuda czy też Realnym Lacana. W toku tego bolesnego procesu podmiot jest uwięziony w przestrzeni granicznej między snem i realnością. Wtedy sen staje się symptomem i zwykle też przypomina znikający punkt czy też, trzymając się anarchicznej metaforyki filmowej, swobodnego jeźdźca w nieokreślonej rzeczywistości' ${ }^{19}$. Może z tych powodów autor Sennika polskiego... nie ustalił cech tożsamości zbiorowej - narodowej, pokoleniowej, historycznej, lecz zrzucił to na Czytelnika. Zatem jako czytelniczka stwierdzam, że pokrętna materia snów nie poddaje się łatwo wnioskom ani uogólnieniom, ponieważ sny zarówno warunkują, jak i uniemożliwiają swobodne kształtowanie się podmiotu i wielostronne budowanie jego tożsamości. Literackie przetworzenia marzeń sennych w takim samym stopniu mogą integrować, jak i dezorganizować przeżycia, wspomnienia, emocje w życiu psychicznym jednostek oraz zbiorowości.

Przypuszczam, że brak konkluzji na temat tożsamości kolektywnej w książce Owczarskiego jest rezultatem wielu ważnych zbiegów okoliczności, na które składają się: paradoksalny status podmiotu i tożsamości, stereotypowość pojęcia narodu, rozchwiane kategorie pokolenia i przeżycia

/ wszystko będzie / jasne i zrozumiałe / i nieciekawe..." (Wiersze. Tadeusz Kantor, oprac. P. Stangret, "Teksty Drugie" 2005 nr 6, s. 210-211).

19 Nawiązuję do filmów: Znikający punkt (1971), reż. R.C. Sarafian; Swobodny jeździec (1969), reż. D. Hopper. 
pokoleniowego. A historia, tak często przywoływana przez autora Sennika polskiego, jak zwykle płynie kilkoma nurtami i zawsze najciekawsze są jej meandry. Jednym z tych zakrętów jest frapujące stwierdzenie Jonathana Crary'ego dotyczące związków snu z systemem polityczno-społecznym, opozycyjne wobec opinii Owczarskiego, który uważa, że: „Obfitująca w nieszczęście Historia wymagała od nas nieprzerwanego niemal stanu czuwania"20 $\mathrm{w}$ czasach romantycznych spisków i w dobie „wzorowanego na kulturze zachodniej wyścigu szczurów”"21. Według Crary'ego „sen jest jednym z tych niewielu pozostałych nam stanów, w których - świadomie lub nie - zdajemy się na opiekę innych"22 i stawiamy opór (samodzielnie lub we wspólnocie) niepojmowalnej rzeczywistości, w której z trudem możemy realizować swoje senne i bezsenne marzenia.

\section{Abstract}

\section{Iwona Misiak}

CARDINAL STEFAN WYSZYŃSKI UNIVERSITY (WARSAW)

Polish Literary Dreams

Review: W. Owczarski, Sennik polski: Literatura, wyobraźnia i pamięć [A Polish Dream Book: Literature, the Imagination, Memory], słowo/obraz terytoria, Gdańsk 2014.

\section{Keywords}

dream, dream studies, imagination, history, identity

\footnotetext{
20 W. Owczarski Sennik polski, s. 6.

21 Tamże.

22 J. Crary 24/7. Późny kapitalizm i koniec snu, przeł. D. Żukowski, Karakter, Kraków 2015, s. 201.
} 